\title{
Comparative Score -1
}

National Cancer Institute

\section{Source}

National Cancer Institute. Comparative Score -1. NCI Thesaurus. Code C126682.

A score of -1 on a comparative scale that ranges from 3+: Very much better to -3: Very much worse. 